Bushy tank are:-effective length, 500 feet; depth of water, 12.5 feet; breadth of water, 30 feet; area of crosssection, 40 square yards; breadth of building, 42 feet; breadth of carriage, $3 \mathrm{I}$ feet; weight of carriage, to tons; velocity of carriage, 25 feet per second; horse-power on carriage, 50. The opinions expressed by the members at the meeting indicate that they arc satisfied that these dimensions will amply provide for, not only ordinary commercial problems, but also for any special problems that may arise. One of the first systematic researches after the tank has settled down to its work will be the investigation of the many propeller problems regarding which little or no knowledge exists.

\section{RURAL EDUCATION IN ITS VARIOUS GRADES.}

THIS subject was discussed at a conference of the County Councils' Association held at Caxton Hall, Westminster, on March 31, under the presidency of $\mathrm{Mr}$. Henry Hobhouse. The conference had been convened at the request of the Central Land Association, the Central Chamber of Agriculture, and the Farmers' Club, and was in every sense thoroughly representative.

A resolution was moved by Sir J. Cockburn to the effect that local education authorities should aim at securing better instruction in rural subjects, and that the teaching should be adapted to the circumstances of country life; school gardens and equipment for manual instruction should be provided, and elementary-school teachers should be specially trained for their work. The resolution was referred to a special committee.

To those unacquainted with country schools it must come as a surprise that such a resolution should be necessary nearly forty years after elementary education became the business of a Government department. Yet, as a matter of fact, it is only within quite recent years that the education of the country child has begun to have any sort of relation to his environment; he has been taught the same subjects as the town child, and in the same way, but often not quite as well. The teaching has been didactic, and has not necessarily involved any observation by the child of the things happening outside the school doors. For this the teacher has not been to blame, for country teachers, as a class, have as keen a professional spirit as town teachers, but the system has been at fault. Country children are sometimes said to be less intelligent than town children of the same class. This is emphatically not the case; on the contrary, the country child has often a larger stock of experience than the town child, and a proper system of education, based on his experience and dealing with the things about him, ought to give admirable results. It is much to be hoped that Sir J. Cockburn's resolution will be acted upon by those in authority.

After-education was also dealt with. The more promising children, it was urged, should be sent to secondary schools, where nature-study and elementary science teaching were given in close connection with practical work in the workshop and garden. The idea is admirable, but there would be considerable difficulty in getting to the school, especially in winter; while, if the children had to board at the school, the numbers would necessarily be very limited. Both elementary and secondary schools would remain under the Board of Education, but the more special agricultural education, the conference considered, should be dealt with by the Board of Agriculture. It was proposed that each group of counties should be connected with some agricultural college, which should be responsible for educating the students sent there, and for giving lectures and other instruction to farmers who cannot attend college. This system is already at work in some places, and was discussed in NATURE for March 25.

It will be observed that the resolutions were very comprehensive in their scove, and adequately covered the various problems of rural education. Whether the Boards of Education and of Agriculture could carry through so bold a scheme remains to be seen : it is undoubtedly to the interests of rural districts that they should.

To those wishing to learn the present position of higher

$$
\text { No. } 2058 \text {, VOL. } 80]
$$

agricultural education in England, a White Paper (Cd. 4569 ) issued by the Board of Education, giving certain tables of expenditure, will be useful. It was not possible to ascertain the exact amount spent on higher agricultura education, because in many cases agriculture only forms part of the work, and a fine estimate of what it receives is impossible. The Board of Agriculture grants are, of course, entirely ad hoc, but the Board of Education grants are for the whole institution. We find that the former Board gives $880 \mathrm{ol}$. a year to colleges of university standing in England and 335ol. to smaller colleges and schools. The Board of Education gives $72,856 l$. and $25,496 l$. respectively. In one way and another the County Council grants must be considerable, but as a whole institution is often involved it is impossible to work out the exact share that agriculture gets. Four counties, viz. Bucks, Cumberland, Herefordshire, and Wiltshire, all active in providing rural education, spend between them about Io,oool. annually. The paper goes on to point out that the Board of Education is prepared to give still higher grants when a properly coordinated scheme is submitted to it, and we should imagine that considerable advantage will be taken of the offer.

\section{SOME MARINE AND FRESH-WATER ORGANISMS.}

$\mathrm{N}$ the first part of vol. xcii. of Zeitschrift für wissen schaftliche Zoologie, Mr. L. Luders gives a full description of the wonderful ostracod crustacean described by Müller in 1895 under the name of Gigantocypris agassizi, together with a brief reference to the second species of the same genus. The first evidence of the typical species was a specimen dredged in deep water off Prince Edward's Island during the cruise of the Challenger, which indicated a veritable giant in the group, the shell measuring no less than $25 \mathrm{~mm}$. in length and $16 \mathrm{~mm}$. in width. Of the soft parts only the head was preserved, but this and the shell were sufficient to indicate the distinctness of the species from all shallow-water forms, and it was suggested at the time that it might prove to represent a new family group. In I89 other examples were dredged by the Albatross off the Pacific coast at depths of as much as 1700 fathoms, and these were duly described and named by G. W. Müller. Another specimen was obtained by the Prince of Monaco off the Azores, while later still several others were dredged in deep water by the Valdivia. It is these last which form the subject of Mr. Luders's paper, where full details of the external form and anatomy of the species are given. One of the specimens collected by the Valdivia was dredged in the Gulf of Guinea, while the others were obtained in widely separated localities. This, together with the structure of the shell, suggests that it is a deep-sea pelagic organism, which does not, like other ostracods, live in sand.

In connection with the foregoing may be conveniently noticed a paper by Dr. Esther Byrnes on the fresh-water species of Cyclops of Long Island, published in No. vii. of Cold Spring Harbour Monographs. The observations in this monograph, which are based on several years' work, have special reference to the variability displayed by the fresh-water species of these crustaceans. Those from Long Island agree generally with the forms from the rvestern lakes, and indicate their wide distribution. Variation of a varietal type is strongly developed, but much more so in some species than in others; it attains its maximum in the forms inhabiting stagnant waters, which can only exist at all by the power of readily adapting themselves to environment. Size is largely dependent upon habitat.

The American snapping shrimps of the genus Synalpheus form the subject of a memoir by Mr. Henri Coutière, published as No. 1659 (vol. xxxvi., pp. I-93) of the Proceedings of the U.S. National Museum. Previous to the appearance of this paper six American species of the group were nominally recognised, under the generic title of Alpheus, but the author is unable to retain more than three of these names. On the other hand, he names a considerable number of new species, not only from American waters, but from other parts of the world. In No. 1663 of the Proceedings of the U.S. National Museum (vol. xxxvi., pp. 173-7) Miss H. Richardson describes a specimen, from Wood's Holl, 